\title{
RELATIONS OF SECONDARY STUDENTS' INTRINSIC MOTIVATION AND ASPIRATIONS WITH THEIR SELF-CONCEPT IN SCIENCE
}

\author{
N. W. L. Narangodaa ${ }^{1} \square$ (iD, W.D. Chandrasenab ${ }^{2}$, H. M. S. P. Madawala ${ }^{3}$ (iD \\ 1, 2 Postgraduate Institute of Science, University of Peradeniya, Peradeniya, Sri Lanka. \\ ${ }^{3}$ Department of Botany, Faculty of Science, University of Peradeniya, Peradeniya, Sri Lanka
}

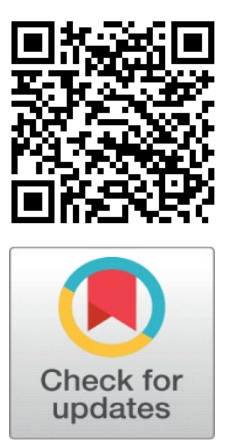

Received 10 September 2021

Accepted 20 October 2021

Published 31 October 2021

\section{Corresponding Author}

N. W. L. Narangodaa, wathsi.nwl@gmail.com

\section{DOI}

10.29121/granthaalayah.v9.i10.2021 .4318

Funding: This research received no specific grant from any funding agency in the public, commercial, or not-for-profit sectors.

Copyright: (C) 2021 The Author(s). This is an open access article distributed under the terms of the Creative Commons Attribution License, which permits unrestricted use, distribution, and reproduction in any medium, provided the original author and source are credited.

\section{ABSTRACT}

Science is a critical area as it focuses on meeting basic human needs by laying the necessary foundation in everybody in diverse fields. Thus, science impacts everybody in the world and science education demonstrate utmost important. If students have intrinsic motivation, they are well engaged, enquiring, attentive and willing to participate in learning process and the intrinsically motivated behaviors help them acquire knowledge and experience regarding science. Educational aspirations, career aspirations and self-concept promote for better science education. Thus, the present study aimed to address the relations of secondary students' intrinsic motivation and aspiration with their self-concept in science. This is a mixed methods study and sample comprised 2384 students in Grade 8 and Grade 9. In this study, an intervention was implemented to explore students' intrinsic motivation, aspirations and self-concept using appropriate teaching methodologies and strategies; results reveal that, there were strong positive relationships of students' intrinsic motivation and aspirations with their self-concept (r2 $=.934 ; .926$ respectively) in the experimental group. However, there were very low positive relationships of students' intrinsic motivation and aspirations with their selfconcept ( $\mathrm{r} 2=.093 ; .058$ respectively) in the control group. Further, there were significant differences of students' intrinsic motivation, aspirations and self-concept before and after the intervention in the experimental group; $t=51.926(1232) \mathrm{p}=.000 ; t=48.513(1232)$ $p=.000 ; t=53.689(1232) p=.000$ respectively. There was no such significant difference of the above, before and after the intervention in the control group; $t=-.5(1150) p=.323 ; t=-$ $.989(1150) \mathrm{p}=.116 ; \mathrm{t}=1.572$ (1150), $\mathrm{p}=.617$ respectively. The findings of the study provided greater understanding of the above relations, develop suitable teaching and learning methodologies and inform the practice of science education.

Keywords: Intrinsic Motivation, Self-Concept, Aspirations

\section{INTRODUCTION}

Science has been simply defined as an organized body of knowledge. On the other hand science education simply refers to the combination of teaching, learning, and research. Knowledge of science and mathematics is the basis for personal accomplishment and responsible citizenship, social and economic development and it is the benchmark of innovation, entrepreneurship and competitiveness the global world (Gilbert (1991)). Thus, science education is important everywhere in this world. 
Intrinsic motivation and autonomy support of the teacher are helping to perform well in science teaching-learning process. Intrinsic motivation initiates, directs and maintains all behaviors related to education in students. Intrinsic motivation and attention are very much connected in the classroom in all areas of activities in teaching-learning process. According to the Self-Determination Theory, external rewards, positive feedback, positive reinforcements and other positive extrinsic events enhance intrinsic motivation of the students. In this aspect, teachers choose to motivate students powerfully to enhance their interest, engagement, selfconcept, and wellbeing in the classroom (Deci and Ryan, 2000). On the other hand, Ryan et al. (1990) showed a relation between intrinsic motivation and learning. Students who were intrinsically motivated for the reading who found it interesting and enjoyable subsequently did better on an unexpected test. Hence, teachers who are autonomy supportive effectively facilitate intrinsic motivation. Even lesson to lesson variations in students' interest and motivation are a function of fluctuations in the teachers' support for autonomy. Thus, according to the Self -Determination theory, teacher should listen to students, making time for students' independent work, giving opportunity to talk, acknowledging signs of improvements and mastery, encouraging students' efforts, being responsive to students' comments and questioning. When learners are motivated, they are much more likely to give a higher level of attention than in situation when motivation is poor. Motivation and effort overtime, specially is supported by a good teacher, typically results in better learning outcomes (Maslow, 1962). Thus, good teacher, should improve the intrinsic motivation of the students them it helps to improve and create fruitful and meaningful science education.

Education aspiration is a sum of other level of aspiration goals, such as career goals, occupational goals, life style wealth etc. Every student has educational aspirations. It is a decision which the individual inspires about what he/she wants to become in life and what course he or she wants to study. Science understanding and ability also enhance the capability of students to hold meaningful and productive careers in the future. It means career aspiration of the students affects to the future careers and it may provide fruitful life in their future. The future world needs entry level workers with the ability to inspire reasons, think creatively, make decisions, analyze and solve problems according to the scientific method. Thus, in the resent investigation, teaching methodologies are well developed to enhance students' educational aspirations career aspirations and also intrinsic motivation and self-concept in science.

Shavelson et al. (1976) have defined self-concept concisely as 'a person's perception of himself formed through his experience with his environment'. Chiu (2008) refers to science self-concept as the confidents that student have in their capacity to learn science. Hence, it is reasonable to consider that a positive selfconcept would be valued as a desirable or critical goal across many educational settings (Brookover and Lezotte (1979)). In support of deeming self-concept as an important educational factor, previous research has shown that higher levels of selfconcept are linked to various education outcomes such as academic effort, course work selections, educational aspirations and academic achievements (Marsh and Graven 1997; Marsh and Hau (2003))

There is strong association between science aspiration occurred with extrinsic motivation followed by intrinsic motivation, self-concept also had a positive association with science aspirations. Furthermore, providing students with the opportunity to take part in hands on practical lessons, engagement with science extra-curricular activities and showing how science relates to everyday life are all associated with students' aspirations to continue with science education. 
However, there is a dearth of research investigation relations among students science self-concept, intrinsic motivation, aspirations in different domains in science in the Sri Lankan context. On the other hand, a comprehensive study has not been conducted to identify key psychological drivers that influence the uptake of science education. Thus, the main aim of the present study was to address this gap in the literature by investigation the relations of secondary students' intrinsic motivation and aspirations with their self-concept in science.

\section{RESEARCH AIM, OBJECTIVES, RESEARCH QUESTIONS AND THEIR RATIONALE \\ 2.1. RESEARCH AIM}

The main aim of the present study was to investigate the relations of secondary students' intrinsic motivation and aspirations with their self-concept in science to make suggestions to enhance students' meaningful learning in science.

\subsection{RESEARCH OBJECTIVES}

1) To investigate the students' intrinsic motivation, self-concept and aspirations before intervention.

2) To use different methods of teaching for experimental and control groups.

3) To determine the relations of students' intrinsic motivation and aspirations with their self- concept in science in both experimental and control groups.

4) To make suggestions to enhance meaningful learning in Grade 8 and Grade 9 science students.

\subsection{RESEARCH QUESTIONS}

1.1 What are the students' existing intrinsic motivation, aspirations and selfconcept?

2.1 What are the teaching methods used to be teach selected lessons to improve students'

intrinsic motivation, aspirations and self- concept in science in the experimental groups?

2.2 What are the teaching methods used to be teach selected lessons in the control group?

3.1 What are the students' intrinsic motivation, aspirations and self- concept after the

intervention in experimental group?

3.2 What are the students' intrinsic motivation, aspirations and self-concept after the

intervention in control group?

3.3 What are the relations of students' intrinsic motivation and aspirations with their self-concept

in science?

4.1 What are the suggestions can be made towards meaningful learning in science in Grade 8 and

Grade 9 in Sri Lanka? 


\section{RATIONALE}

Science education leads to individual careers in any number of scientific disciplines, a general understanding of the scientific and technological foundations of the world we live in is just as prevalent to almost any other employment, and to daily life. The burning issue of declining students' enrolment in science must be addressed, to ensure that science is advanced in Sri Lanka. Today's science students are tomorrow's inventors, medical researchers, engineers, teachers and leaders to promote the country in the international level.

Past research in other countries, suggests that the decline in science education is related to students' motivation, academic abilities, and teaching methods (Hassan and Treagust (2003)). However, a comprehensive study has not been conducted to identify key psychological drivers and to investigate the relations between such drivers and engagement in science in Sri Lanka. However, there is a dearth of research investigation relations among students science self-concept, intrinsic motivation, aspirations in different domains in science in Sri Lanka. On the other hand, a comprehensive study has not been conducted to identify key psychological drivers that influence the uptake of science education. Thus, the main aim of the present study was to address this gap in the literature by investigation the relations of secondary students' intrinsic motivation and aspirations with their self-concept in science.

\section{METHODOLOGY 4.1. METHOD}

The study used mixed methods of study. As such, both qualitative and quantitative approaches were used in the process of data collection and data analysis. The research design was the experimental research design. Items of questionnaires were carefully chosen that addressed domains of secondary students' intrinsic motivation, self-concept and aspirations related to science.

\subsection{DATA COLLECTION}

Sampling: Convenience sampling technique was used. Participants comprised 2384 students from Grade 8 and Grade 9 at 19 schools in Dehiowita and Kegalle educational zones at Sabaragamuwa province in Sri Lanka. Control group and experimental group consisted with 1151 students and 1233 students respectively.

Procedure: Ethical approval were obtained from the director of postgraduate institute of science, University of Peradeniya; the directress of zonal education, Dehiowita educational zone, the director of zonal education Kegalle educational zone, relevant school principals and the participants. Students were divided into two groups as control and experimental groups based on pretest marks. Different teaching learning methodologies and strategies were applied to experimental and control groups separately according to the lesson plans. Discussions, debates, role playing, games, writing and speaking exercise, classroom assessments, group works, presentations and practical were used as teaching methodologies for the experimental group in the intervention and traditional teaching method was used for the control group. Students' intrinsic motivation, self-concept and aspirations were measured before intervention and after intervention in both groups using the same multidimensional questionnaire.

At the beginning of the intervention it was announced to the students that the data collected would only be used by the researcher for research purposes without 
reporting back the raw data to the schools, parents and other people. Students' were also informed that the consent form they sign in the questionnaire booklet will be removed and stored separately after the research in order to make students' answers confidential without giving others the chance to identify the individuals.

Instrumentation: Students' existing self-concept, intrinsic motivation and aspirations were measured by revised validated multidimensional questionnaire. The same questionnaire was used to measure above factors after the intervention in both experimental and control groups. It consists 6 items for intrinsic motivation, 6 items for self-concepts and 7 items for aspirations (3 items for educational aspirations and 4 items for career aspirations). Students' science marks sheets, registers, Grade 8 and 9 text books, Grade 8 and 9 teachers' instruction manuals were used as documents in data collection.

Focus group interviews and photographs were used as qualitative aspect. Focus group interviews were conducted in every school with 5-6 students in both Grade 8 and 9 in the experimental group. Photographs were taken in everyday in the intervention process in both Grade 8 and 9 in the experimental group.

\subsection{DATA ANALYSIS}

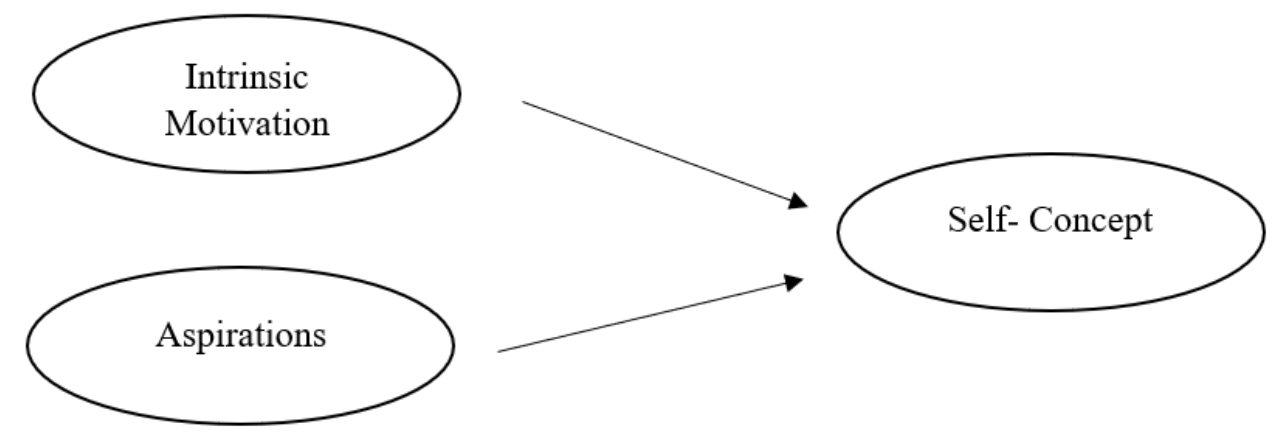

Figure 1 Independent variables and dependent variable of the study

Quantitative data were initially entered in Microsoft Excel sheets were prepared for use in SPSS. Data screening and general analyses (reliabilities, frequencies etc.) were performed using SPSS.22.0.

Descriptive analyses were carried out on the data for students' self-concept, intrinsic motivation aspirations followed by reliability test. The differences between before intervention and after intervention of students' intrinsic motivation, aspirations and self-concept were measured by pared sample t- test $(95 \%$ confidence level) and correlation of intrinsic motivation with self-concept and aspirations with self-concept were measured by linear regression $\left(\mathrm{r}^{2}\right)$. Thematic analysis was used to analyze the qualitative data.

\section{RESULTS AND DISCUSSIONS}

Cronbach's alpha is a measure of internal consistency and reliability which is how closely related a set of items are as a group. Reliability is the degree to which the result of a measurement, calculation, or specification can be depended on to be accurate. Alpha coefficients were ranged between 0.89 and 0.96 of three factors of the multidimensional questionnaire as shown in the Table 1 . Therefore the internal consistency or reliability of those items is excellent $(\geq 0.5)$ in the questionnaire and it can be used as stranded instrument of data collection. 
Table 1 Reliability statistic of factors

\begin{tabular}{ll}
\hline Factor & Cronbach's alpha \\
Self-concept & .890 \\
Intrinsic Motivation & .937 \\
Aspiration & .965
\end{tabular}

The above Cronbach's alpha values show high degree of reliability of the instrument used.

Research Question 1.1: Students' existing intrinsic motivation, aspirations and self-concept in experimental group and control group

Descriptive statistics were done to measure mean values of existing students' intrinsic motivation, aspirations and self-concept of the both experimental group and control group. Mean statistics of existing self- concept, intrinsic motivation and aspirations in the experimental group were represented in Table 2.

Table 2 Mean statistics of self-concept, intrinsic motivation and aspirations of experimental group

\begin{tabular}{cccccc}
\hline & N & Range & Minimum & Maximum & Mean statistics \\
MSCBE & 1233 & 5 & 1 & 6 & 2.6365 \\
MMBE & 1233 & 5 & 1 & 6 & 2.7583 \\
MABE & 1233 & 5 & 1 & 6 & 2.5134 \\
\hline
\end{tabular}

NB: MSCBE=mean value of self-concept before intervention in experimental group, $\mathrm{MMBE}=$ mean value of motivation before intervention in experimental group, $\mathrm{MABE}=$ mean value of aspirations before intervention in experimental group.

Mean values of all three factors were around 2.5. The median value of this range was 3 . But the mean values were less than the median. Hence, students' existing intrinsic motivation, aspirations and self-concepts were low towards science in the sample of experimental group.

On the other hand, mean statistics of existing self-concept, intrinsic motivation and aspirations in the control group were represented in Table 3.

\begin{tabular}{cccccc}
\hline \multicolumn{5}{c}{ Table 3 Mean statistics of self-concept, intrinsic motivation and aspirations of control group } \\
\hline & N & Range & Minimum & Maximum & Mean statistics \\
MSCBC & 1151 & 5 & 1 & 6 & 2.4681 \\
MMBC & 1151 & 5 & 1 & 6 & 2.5777 \\
MABC & 1151 & 5 & 1 & 6 & 2.3717 \\
\hline
\end{tabular}

NB: $\mathrm{MSCBC}=$ mean valve of self-concept before intervention of control group, $\mathrm{MMBC}=$ mean value of intrinsic motivation before intervention in control group, $\mathrm{MABC}=$ mean value of aspirations before intervention in control group. 
Mean values of all three factors were around 2.5. The median value of this range was 3 . But the mean values were less than the median. Hence, students existing intrinsic motivation, aspirations and self-concepts were low towards science in the sample of the control group.

Mean descriptive of self-concept, intrinsic motivation and aspirations were ranged 2.513 to 2.758 in experimental group and also mean descriptive of selfconcept, intrinsic motivation and aspirations were ranged 2.371 to 2.577 in control group. In this aspect, there is no difference between students' existing self-concept, intrinsic motivation and aspirations of experimental group and control group.

Research Question 2.1 and 2.2: Teaching and learning methodologies in the experimental and control groups

In this aspect to empower the students' intrinsic motivation, aspirations and self- concept, teaching methodologies and teaching strategies were used. Teacher centered classroom was shifted to student centered classroom. According to the Self Determination Theory, positive reinforcements, positive feedback and other positive extrinsic events were established while the teaching- learning process. Rapport was buildup with students and given mental and emotional support to the students.

Traditional teaching learning process was used for control group. The classroom was teacher centered. Discussions, debates, role playing, games, writing and speaking exercise, classroom assessments, group works, presentations and practical were used as teaching methodologies for the experimental group in the intervention. Laboratories, classrooms, outdoor fields, home science room and computer labs were used to follow above methodologies.

Research Question 3.1: Students' intrinsic motivation, self-concept and aspirations after the intervention in the experimental group

In this aspect, students' intrinsic motivation, aspirations and self-concept were measured after intervention using the same multidimensional questionnaire. The descriptive statistics of these three factors were given in the following Tables 4 and 5 .

\begin{tabular}{|c|c|c|c|c|c|}
\hline & $\mathbf{N}$ & Range & Minimum & Maximum & Mean statistics \\
\hline MSCAE & 1233 & 5.00 & 1.00 & 6.00 & 5.7782 \\
\hline MMAE & 1233 & 5.00 & 1.00 & 6.00 & 5.8154 \\
\hline MAAE & 1233 & 5.00 & 1.00 & 6.00 & 5.7646 \\
\hline
\end{tabular}

NB: MSCAE= mean self-concept after intervention of the experimental group, MMAE: mean intrinsic motivation after intervention of the experimental group, MAAE: mean aspirations after intervention of the experimental group.

The maximum value of this range was 6 . In this aspect, mean values of all three factors were around 6 in the experimental group. Therefore, students' mean values of intrinsic motivation, aspirations and self- concept were increased through the intervention process in the experimental group. It means, the teaching methodologies and strategies which were used in the intervention were fruitful and effective. According to the Bomia, Lisa and Beluzo in 1997, teaching strategies support the learners' intrinsic motivation and other emotional and mental concepts, 
specific teaching strategies have a positive effect on the various concept related to intrinsic motivation. Teacher must be aware of strategies that will positively affect intrinsic motivation using the approaches such as positive reinforcements, students' willingness and enthusiasm (Bomia et al. (1997)). They further highlighted that in relation to education, motivation refers to students' willingness, need, desire, and compulsion to participate in and be successful in the learning process; it seeks to increase the factors that move a student toward becoming more involved in the class and the subject matter. Keller (1979) also expressed that use unexpected; rewards use verbal phrase and informative feedback and external performance evaluation are used to improve intrinsic motivation.

In the other hand, higher levels of self-concept in specific domains are linked to various educational outcomes, such as educational aspirations (e.g., Marsh, 1990a; Marsh and Craven, 1997; Marsh and Craven (2006); Marsh and Hau (2003)). Chiu (2008) refers to science self-concept as the confidence that students have in their capacity to learn science. Hence, it is reasonable to consider that across many educational settings a positive self-concept would be valued as a desirable or critical goal (Australian Education Council (1989); Brookover and Lezotte (1979)). Marsh and Craven (1997) said that academic self- concept was enhanced through the experience they gave and the environment that they learnt. Therefore all these researches were given evidences to support the findings of the present study.

Research Question 3.2: Students' intrinsic motivation, aspirations and self- concept after the intervention in the control group.

Table 5 Descriptive statistics of self-concept, intrinsic motivation and aspirations after interventions in control group

\begin{tabular}{cccccc}
\hline & N & Range & Minimum & Maximum & Mean statistics \\
MSCAC & 1151 & 5.00 & 1.00 & 6.00 & 2.4639 \\
MMAC & 1151 & 5.00 & 1.00 & 6.00 & 2.5696 \\
MAAC & 1151 & 5.00 & 1.00 & 6.00 & 2.3855 \\
\hline
\end{tabular}

NB: MSCAC: mean self-concept after the intervention in the control group, MMAC: mean intrinsic motivation after the intervention of the control group, MAAC: mean aspirations after the intervention in the control group

When compare the mean values of three factors before and after interventions of the control group (Tables 3 and 5) there was no difference between the mean values of intrinsic motivation, aspirations and self-concept before and after the intervention. Therefore traditional teaching method was not efficient to improve mean values of intrinsic motivation, aspirations and self- concept of the students in the control group.

Research Question 3.3: Students' intrinsic motivation and aspirations with their self -concept in science in both experimental and control groups 
Table 6 Paired sample t-test of self-concept, intrinsic motivation and aspirations before and after interventions of experimental group

\begin{tabular}{ccc}
\hline Pair & t value & Significant ( $\boldsymbol{p}$ value) \\
MSCAE - MSCBE & 51.926 & .000 \\
MMAE - MMBE & 48.513 & .000 \\
\hline MAAE - MABE & 53.689 & .000 \\
\hline
\end{tabular}

NB: MSCAE-MSCBE: mean self-concept after and before intervention in experimental group, MMAE-MMBE: mean intrinsic motivation after and before intervention in experimental group, MMAE-MABE: mean aspirations after and before interventions in the experimental group.

A value of $p$ less than $0.05(\leq 0.05)$ is statistically significant. The $95 \%$ confidence level ( $p$ value) of all three factors was 0.00 . Therefore, there was a significant difference between self-concept, intrinsic motivation and aspirations after interventions in experimental group. In this aspect, teaching methodologies and teaching strategies were effected to enhance students' self-concept, intrinsic motivation and aspirations in the experimental group.

Table 7 Paired sample t-test of self-concept, intrinsic motivation and aspirations before and after interventions of control group

\begin{tabular}{ccc}
\hline Pair & t value & Significance ( $\boldsymbol{p}$ value $)$ \\
\hline MSCAC - MSCBC & -0.500 & .617 \\
\hline MMAC - MMBC & -0.989 & .323 \\
\hline MAAC - MABC & 1.572 & .116 \\
\hline
\end{tabular}

NB: MSCAC - MSCBC: mean self-concept after and before interventions in control group, MMAC - MMBC: mean intrinsic motivation after and before interventions in the control group, MAAC - MABC: mean aspirations after and before interventions in the control group.

A value of $p$ less than $0.05(\leq 0.05)$ is statistically significant. The $95 \%$ confidence level ( $p$ value) of above three factors in the control group are greater than 0.05. Therefore there is no significant difference between after and before interventions in the control group. In this aspect traditional teaching method was not enhance the students' intrinsic motivation, self-concept and aspirations.

Regression is a statistical technique to formulate the analyze relationship between the defendant variable and independent variable. The independent variables were intrinsic motivation and aspirations and also the dependent variable was self-concept. The aim of that case was to check how the independent variables (intrinsic motivation and aspirations) impact the dependent variable (self-concept). $\mathrm{R}^{2}$ shows the total variation for the self-concept that could be explained by the intrinsic motivation, and aspirations. The values of $r^{2}$ of the three factors in the experimental group are given in the Table 8. 
Table 8 The values of $\mathbf{r}^{2}$ of intrinsic motivation aspirations with self-concept in the experimental group

\begin{tabular}{ccc}
\hline Independent variable & Dependent variable & $\mathbf{r}^{\mathbf{2}}$ (effect size) \\
DIFMOTIE & DIFSCE & .934 \\
\hline DIFASPIE & DIFSCE & .926 \\
\hline
\end{tabular}

NB: DIFMOTIE: difference of mean intrinsic motivation in the experimental group, DIFASPIE: difference of mean aspiration in the experimental group, DIFSCE: difference of mean self- concept in the experimental group.

The values of $\mathrm{r}^{2}$ is greater than 0.5 shows that the model is effective enough to determine the relationships. In this aspect, the value of intrinsic motivation and selfconcept of the student in the experimental group was .934. Therefore there was a strong positive relationship between these two variables, and also the value of students' aspiration and self- concept was .926. Hence, there was a strong positive relationship between students' aspirations and self-concept.

In support of deeming self-concept to be an important educational factor, previous research has shown that higher levels of self-concept are linked to various education outcomes, such as: academic effort, coursework selections, educational aspirations, and academic achievement (e.g., Marsh, 1990a; Marsh and Craven, 1997; Marsh and Hau (2003)). Students' perceptions of themselves (self-concepts) play an important role in their personal aspirations and in their self-expectations (Lynch, 1991), and also influence their academic achievement (Byrne and Shavelson (1996); Hansford and Hattie (1982); Purkey (1970); Shavelson and Bolus (1982); Taylor \& Michael, 1991). As an educational outcome, educational aspirations are linked with higher levels of self-concept (Marsh, 1990a; Marsh and Craven, 1997; Marsh and Hau (2003)). Given the finding of a positive relation between self-concept and academic achievement, it could also be argued that there might be a positive relation between educational aspirations and achievement (Fox and Faver, 1981). On the other hand, there were positive relationship on students' intrinsic motivation and aspirations with self-concept (Chandrasena (2013)). Hence all these previous researches were given evidences to facilitate the current findings. The values of $\mathrm{r}^{2}$ of the intrinsic motivation, aspirations with self-concepts in the control group were given in the following Table 9 .

Table 9 The values of $\mathbf{r}^{2}$ of intrinsic motivation aspirations and self-concept in the control group

Independent variable

$\begin{array}{rrr}\text { DIFMOTIC } & \text { DIFSCC } & .093 \\ \text { DIFASPIC } & \text { DIFSCC } & .058\end{array}$

NB: DIFMOTIC: difference of mean intrinsic motivation in the control group, DIFASPIC: difference of mean aspiration in the control group, DIFSCC: difference of mean self-concept in the control group.

The values of $\mathrm{r}^{2}$ is greater than 0.5 shows, that the model is effective enough to determine the relationships. In this aspect, the values of these variables in control group are less than 0.5 . Therefore there was no relationship among these variables in the control group. 
Research Question 5.1: Suggestions made towards meaningful learning in science in Sri Lanka

Thematic analysis was conducted to derived meaningful themes using focus group interview data. Four themes were derived such as,

Theme 1: Enhancement of intrinsic motivation, self-concept, and aspiration through attractive teaching learning methodologies

Intrinsic motivation, self-concept and aspirations could be enhanced through attractive teaching methods. Students with high intrinsic motivation demonstrate high educational and career aspirations that ultimately support and lead towards students' higher self-concept in science. This is supported by the following evidence from a student.

"I like to learn these types of attractive ways. It gives me some power to learn and willing to learn. I motivated to do home works daily and first of all things at home. Hence I think I am the best person in science in my classroom. I like to learn more science and like to join NASA." (S2/Focus group interviews/Grade 8/ISS/10/09/11).

Theme 2: Rewards on intrinsic motivation

This refers to the benefits due to verbal rewards of the teacher. This is evident by the following response given from a student.

"I like teacher's verbal support. She always admire us. She gives star marks and correction marks in our writing books. L like to see it and it helps me to do science works more and more. I love science." (S5/Focus group interviews/Grade 9/MRV22/10/2019).

Theme 3: Group works on students' retention power

The one of the teaching methods is group work. It was preferred and supported by the following evidence by a student.

"These group works are very important to me. I like to work as a group. It helps to improve our team spirit, mutual understanding, collaborative learning, effectively and friendship. The most important thing is, it improve my retention power. When I go home after school, I like to remind that we do in the group works in the science period satisfactorily. I live this group works. Please teacher, give more group works to us" (S2/Focus group interviews/Grade 8/YSV/08/01/2020).

Theme 4: Assessments on intrinsic motivation

Continuous assessments and summative assessments were done through the intervention process. The following evidence is supported to the above theme from a student.

"Teacher gives test papers after the end of the lesson. I like it. Because it improve our retention power and it measures our ability towards science. Therefore I engage extremely in science to enhance my science knowledge."(S1/Focus group interviews/Grade 9/GWV/02/02/2021).

Moreover, the qualitative results reveal that, attractive teaching and learning methodologies, positive reinforcement and positive feedback on students are enhanced science education in those schools in Sri Lanka. In this aspect, intrinsic motivation, aspirations and self- concept enhance science education.

\section{CONCLUSION, SUGGESTIONS AND LIMITATIONS}

All three factors such as intrinsic motivation, aspirations and self-concept that measured in this study has shown excellent improvements in experimental group when compared to control group, showing positive strong relationships in science. Student centered teaching learning methodologies and teaching strategies were 
enhanced students' intrinsic motivation, aspirations and self-concept in science in the experimental group. In this aspect student centered teaching methodologies were effective and fruitful than the traditional methods of teaching in science.

Except the research findings, this research makes some important suggestions for future activities. Teacher have great role to improve students' intrinsic motivation, self-concept and aspirations. Teacher should provide for practical applications of learning and all scientific concepts relate to their real life. Teacher can determine the learners' expectations and goals then focus instructions to meet those goals.

In this aspect, teachers' attention should be paid to improve the intrinsic motivation, aspirations and self-concept of students. Teachers should be more dedicated and willing to incorporate new and attractive methods in teaching scientific concepts. Hence, teachers should promote learner centered classroom.

This study was conducted within Sabaragamuwa province in Sri Lanka. Thus, the findings of the research couldn't be generalized nationally and internationally. In this aspect, the researcher suggested to do the study deep and with more content in the secondary science with large sample size in order to generalize results.

\section{REFERENCES}

Aikenhead, G. S., and Jegede, O. J. (1999). Cross-cultural science education: A cognitive explanation of a cultural phenomenon. Journal of research in science teaching, 36(3), 269-287. Retrieved from

https://doi.org/10.1002/(SICI)1098-2736(199903)36:3<269::AIDTEA3>3.0.CO;2-T

Aschbacher, P. R., Li, E., \& Roth, E. J. (2010). Is science me? High school students' identities, participation and aspirations in science, engineering, and medicine. Journal of Research in Science Teaching: The Official Journal of the National Association for Research in Science Teaching, 47(5), 564-582. Retrieved from https://doi.org/10.1002/tea.20353

Australian Education Council, (1989). The Hobart Declaration. Melbourne: Australian Education Council.

Bomia, L., Beluzo, L., Demeester, D., Elander, K., Johnson, M., \& Sheldon, B. (1997). The Impact of Teaching Strategies on Intrinsic Motivation. Retrieved from https://eric.ed.gov/?id=ED418925

Brookover, W. B., \& Lezotte, L. W. (1979). Changes in School Characteristics Coincident With Changes in Student Achievement. Occasional Paper No. 17. Retrieved from https://eric.ed.gov/?id=ED181005

Byrne, B. M., \& Shavelson, R. J. (1996). On the structure of social self-concept for pre, early, and late adolescents: A test of the Shavelson, Hubner, and Stanton (1976) model. Journal of personality and social psychology, 70(3), 599. Retrieved from https://doi.org/10.1037/0022-3514.70.3.599

Chandrasena, W., Craven, R., Tracey, D., \& Dillon, A. (2012a). A study of the relations between students' self-concepts, motivation, aspirations and achievement in high school science and chemistry. Retrieved from https://researchdirect.westernsydney.edu.au/islandora/object/uws:1472 6/

Chandrasena, W. (2013). Seeding science success: relations of secondary students' science self-concepts and motivation with aspirations and achievement.

Chiu, M. S. (2008). Achievements and self-concepts in a comparison of math and science: exploring the internal/external frame of reference model across 28 
countries. Educational Research and Evaluation, 14(3), 235-254. Retrieved from https://doi.org/10.1080/13803610802048858

Deci, E. L., \& Ryan, R. M. (2010). Intrinsic motivation. The corsini encyclopedia of psychology, 1-2. $\quad$ Retrieved https://doi.org/10.1002/9780470479216.corpsy0467

Deci, E., and Ryan, R. M. (1985). Intrinsic motivation and self-determination in human behavior. Springer Science \& Business Media. Retrieved from https://doi.org/10.1007/978-1-4899-2271-7

Elliott, A.J., \& Dweck, C.S. (2005). Handbook of competence and motivation. New York:

Elton, L. (1988). Student motivation and achievement. Studies in Higher Education, 13(2), 215-221. Retrieved from https://doi.org/10.1080/03075078812331377886

Fan, X., \& Chen, M. (2001). Parental involvement and students' academic achievement: A meta-analysis. Educational psychology review, 13(1), 1-22. Retrieved from https://doi.org/10.1023/A:1009048817385

Fox, M. F., \& Faver, C. A. (1981). Achievement and aspiration: patterns among male and female academic-career aspirants. Sociology of Work and Occupations, 8(4), 439-463. Retrieved from https://doi.org/10.1177/073088848100800403

Gilbert, S. W. (1991). Model building and a definition of science. Journal of Research in Science Teaching, 28(1), 73-79. Retrieved from https://doi.org/10.1002/tea.3660280107

Guay, F., Larose, S., \& Boivin, M. (2004). Academic self-concept and educational attainment level: A ten-year longitudinal study. Self and identity, 3(1), 5368. Guilford Press. Retrieved from https://doi.org/10.1080/13576500342000040

Guthrie, J. T., \& Wigfield, A. (1999). How motivation fits into a science of reading. Scientific studies of reading, 3(3), 199-205. Retrieved from https://doi.org/10.1207/s1532799xssr0303_1

Hansford, B. C., \& Hattie, J. A. (1982). The relationship between self and achievement/performance measures. Review of Educational Research, 52(1), 123-142. Retrieved from https://doi.org/10.3102/00346543052001123

Hassan, G., \& Treagust, D. F. (2003). What is the future of science education in Australia? Australian Science Teachers Journal, 49(3), 6-15.

Marsh, H. W., \& Craven, R. G. (2006). Reciprocal effects of self-concept and performance from a multidimensional perspective: Beyond seductive pleasure and unidimensional perspectives. Perspectives on psychological science, 1(2), 133-163. Retrieved from https://doi.org/10.1111/j.17456916.2006.00010.x

Marsh, H. W., \& Hau, K. T. (2003). Big-Fish--Little-Pond effect on academic selfconcept: A cross-cultural (26-country) test of the negative effects of academically selective schools. American psychologist, 58(5), 364. Retrieved from https://doi.org/10.1037/0003-066X.58.5.364

Marsh, H. W., and Shavelson, R. (1985). Self-concept: Its multifaceted, hierarchical structure. Educational psychologist, 20(3), 107-123. Retrieved from https://doi.org/10.1207/s15326985ep2003_1 
Marsh, H. W., Vallerand, R. J., Lafrenière, M. A. K., Parker, P., Morin, A. J., Carbonneau, N., \& Abduljabbar, A. (2013). Passion: Does one scale fit all? Construct validity of two-factor passion scale and psychometric invariance over different activities and languages. Psychological Assessment, 25(3), 796. Retrieved from https://doi.org/10.1037/a0032573

Mart, C.T. (2013). A passionate teacher: Teacher commitment and dedication to student learning. International Journal of Academic Research in Progressive Education and Development, 2(1), 437-442. Retrieved from https://www.researchgate.net/profile/Cagri-Mart-

2/publication/329155635_A_passionate_teacher_Teacher_commitment_an d_dedication_to_student_learning/links/5bfb8d49458515a69e3bd1f3/Apassionate-teacher-Teacher-commitment-and-dedication-to-studentlearning.pdf

McLeod, S. (2007). Maslow's hierarchy of needs. Simply psychology, 1, 1-8. Retrieved from https://canadacollege.edu/dreamers/docs/MaslowsHierarchy-of-Needs.pdf

Mishra, S. (2013). Science attitude as a determinant to educational aspiration in students. International Journal of Engineering Inventions, 2(9), 29-33. Retrieved from https://www.researchgate.net/profile/Savita-Mishra3/publication/342802586_Science_Attitude_as_a_Determinant_to_Educati onal_Aspiration_in_Students/links/5f06b7a8a6fdcc4ca459a44e/ScienceAttitude-as-a-Determinant-to-Educational-Aspiration-in-Students.pdf

Niemiec, C. P., \& Ryan, R. M. (2009). Autonomy, competence, and relatedness in the classroom: Applying self-determination theory to educational practice. School Field, 7(2), 133-144. Retrieved from https://doi.org/10.1177/1477878509104318

Pascarella, E. T. (1984). College environmental influences on students' educational aspirations. The Journal of Higher Education, 55(6), 751-771. Retrieved from https://doi.org/10.2307/1981512

Purkey, W. W. (1970). Self- concept and school achievement. Retrieved from https://eric.ed.gov/?id=ED058359

Reynolds, R., \& Chiu, M. M. (2012, July). Contribution of motivational orientations to student outcomes in a discovery-based program of game design learning. In International Conference of the Learning Sciences (ICLS). Retrieved from https://papers.ssrn.com/sol3/papers.cfm?abstract_id=2333922

Ryan, R. M., Connell, J. P., \& Plant, R. W. (1990). Emotions in nondirected text learning. Learning and individual differences, 2(1), 1-17. Retrieved from https://doi.org/10.1016/1041-6080(90)90014-8

Ryan, R. M., \& Deci, E. L. (2000). Self-determination theory and the facilitation of intrinsic motivation, social development, and well-being. American psychologist, 55(1), 68. Retrieved from https://doi.org/10.1037/0003066X.55.1.68

Ryan, R., \& Deci, E. (2000). Intrinsic and extrinsic Motivations: Classic definitions and new directions. Contemporary Educational Psychology, 25, 54-67. Retrieved from https://doi.org/10.1006/ceps.1999.1020

Serin, H. (2018). The use of extrinsic and intrinsic motivations to enhance student achievement in educational settings. International Journal of Social Sciences \& Educational Studies, 5(1), 191-194. Retrieved from https://doi.org/10.23918/ijsses.v5i1p191 
Shavelson, R. J., \& Bolus, R. (1982). Self- concept: The interplay of theory and methods. Journal of educational Psychology, 74(1), 3. Retrieved from https://doi.org/10.1037/0022-0663.74.1.3

Shavelson, R. J., Hubner, J. J., \& Stanton, G. C. (1976). Self-concept: Validation of construct interpretations. Review of educational research, 46(3), 407-441. Retrieved from https://doi.org/10.3102/00346543046003407

Shrake, D. L., Elfner, L. E., Hummon, W., Janson, R. W. and Free, M. (2006). What is science?.

Sproule, J., Wang, C. J., Morgan, K., McNeill, M., \& McMorris, T. (2007). Effects of motivational climate in Singaporean physical education lessons on intrinsic motivation and physical activity intention. Personality and Individual Differences, 43(5), 1037-1049. Retrieved from https://doi.org/10.1016/j.paid.2007.02.017

Taormina, R. J., \& Gao, J. H. (2013). Maslow and the motivation hierarchy: Measuring satisfaction of the needs. The American journal of psychology, 126(2), 155177. Retrieved from https://doi.org/10.5406/amerjpsyc.126.2.0155

Zielinski, C. M., Taylor, M. A., \& Juzwin, K. R. (1991). Neuropsychological deficits in obsessive-compulsive disorder. Neuropsychiatry, Neuropsychology, \& Behavioral Neurology. Retrieved from https://psycnet.apa.org/record/1991-30592-001

Tharmaseelan, N. (2007). Tertiary education in Sri Lanka: Issues and challenges. Bulgarian Journal of science and education policy, 1(1), 173-190. Retrieved from https://www.researchgate.net/profile/Nithya-Tharmaseelan2/publication/44279664_Tertiary_Education_in_Sri_Lanka_Issues_and_Cha llenges/links/00b49527dafb89f685000000/Tertiary-Education-in-SriLanka-Issues-and-Challenges.pdf

Ventegodt, S., Merrick, J., \& Andersen, N. J. (2003). Quality of life theory III. Maslow revisited. The Scientific World JOURNAL, 3, 1050-1057. Retrieved from https://doi.org/10.1100/tsw.2003.84

Wang, J., \& Staver, J. R. (2001). Examining relationships between factors of science education and student career aspiration. The Journal of Educational Research, 94(5), 312-319. Retrieved from https://doi.org/10.1080/00220670109598767

Yeung, A. S., \& Mcinerney, D. M. (2005). Students' school motivation and aspiration over high school years. Educational Psychology, 25(5), 537-554. Retrieved from https://doi.org/10.1080/01443410500046804

Zeyer, A., and Wolf, S. (2010). Is there a relationship between brain type, sex and motivation to learn science?. International Journal of Science Education, 32(16), 2217-2233. Retrieved from https://doi.org/10.1080/09500690903585184 